\title{
Spatial variations of local climate at Taylor Dome, Antarctica: implications for paleoclimate from ice cores
}

\author{
E. D. Waddington ANd D. L. Morse \\ Geophysics Program, AK-50, University of Washington, Seattle, WA 98195, U.S.A.
}

\begin{abstract}
Antarctic plateau to estimate mean annual air temperatures. $10 \mathrm{~m}$ firn temperatures measured at Taylor Dome (also referred to as McMurdo Dome in the literature), Antarctica, are influenced by a factor other than altitude and latitude that varies systematically across Taylor Dome. Some inter-rclated factors possibly contributing to the modern temperature variability are differences in sensible heat from warm or cold air masses, differences in wind strength and source region, differences in temperaturcinversion strength and differences in cloudiness. Our preliminary data are compatible with spatially variable katabatic winds that could control the winter temperatureinversion strength to provide a large part of the signal. This has implications for paleoclimate studies. (1) Variations of the stable isotopes $\delta^{18} \mathrm{O}$ and $\delta \mathrm{D}$ from ice cores are a proxy for paleotemperature. The isotope thermometer is calibrated by comparing local isotope ratios with corresponding measured tempcratures. In order to derive a useful isotope-temperature calibration, we must understand the processcs that control the modern spatial variability of temperature. (2) In order to quantify past changes in local climate, we must understand processes that influence local spatial variability. If those processes differed in the past, ice-core climate reconstruction would be affected in two ways: through alteration of the geochemical record and through alteration of deep ice and firn tcmperatures.
\end{abstract}

\section{INTRODUCTION}

The Antarctic ice sheet exerts a large influence on Earth's climate. On the local scale, there is a continual interaction among processes such as wind, radiation balance and tcmpcrature variations of the snow surface (Schwerdtfeger, 1970, 1984); in particular, the surface-energy balance and katabatic wind patterns are highly inter-related. The Antarctic ice sheet also contains a record of past climate which can be recovered through ice-core analysis. A broad spectrum of global, regional and local climate processes contribute to the ice-core paleoclimate record. The result can be a rich and varied climate resource to be exploited or a bewildering and uninterpretable muddle to be avoided, depending on the quality of the data and the physical understanding applied to the problem. Both the geochemical signal in the ice and the deep ice temperatures could be affected if spatial patterns of local climate differed in the past. Migration of an ice divide with an associated wind and temperature microclimate could cause such changes at an ice-core sitc. We present preliminary climate data and consider local climate processes that may influence interpretation of ice-core records from Taylor Dome (also sometimes called McMurdo Dome), Antarctica.

\section{Taylor Dome}

Taylor Dome is centered at $77^{\circ} 45^{\prime} \mathrm{S}, 159^{\circ} 00^{\prime} \mathrm{E}$ (Fig. 1), near the edge of the Last Antarctic plateau and adjacent to the McMurdo Dry Valleys. It has topographic closure of about $100 \mathrm{~m}$ and horizontal scale of $100 \mathrm{~km}$. It was first identified as a separate topographic feature by Drewry (1980, 1982), who recognized that ice from Taylor Dome, rather than ice from the central East Antarctic plateau, was the source for glaciers that enter the Dry Valleys. Taylor Dome is expected to have a good geochemical palcoclimate record preserved in the ice, because the accumulation of approximately $0.1 \mathrm{mice}^{-1}$ (Drewry, 1983 ) is higher there than at other domes in East Antarctica, and even the deepest ice is thought to originate locally. A geophysical, geochemical and stratigraphic research program was started in December 1990 to identify the characteristics of the local depositional environment and to select an ice-coring site (Grootes and others, 1991; Waddington and others, 1991, 1993; Grootes and Steig, 1992a; Morse and Waddington, 1992 , in press). An ice core is scheduled to be drilled to bedrock in December 1993 at Taylor Dome.

\section{Firn temperatures and the isotope thermometer}

In regions of ncgligible summer melting, as found 


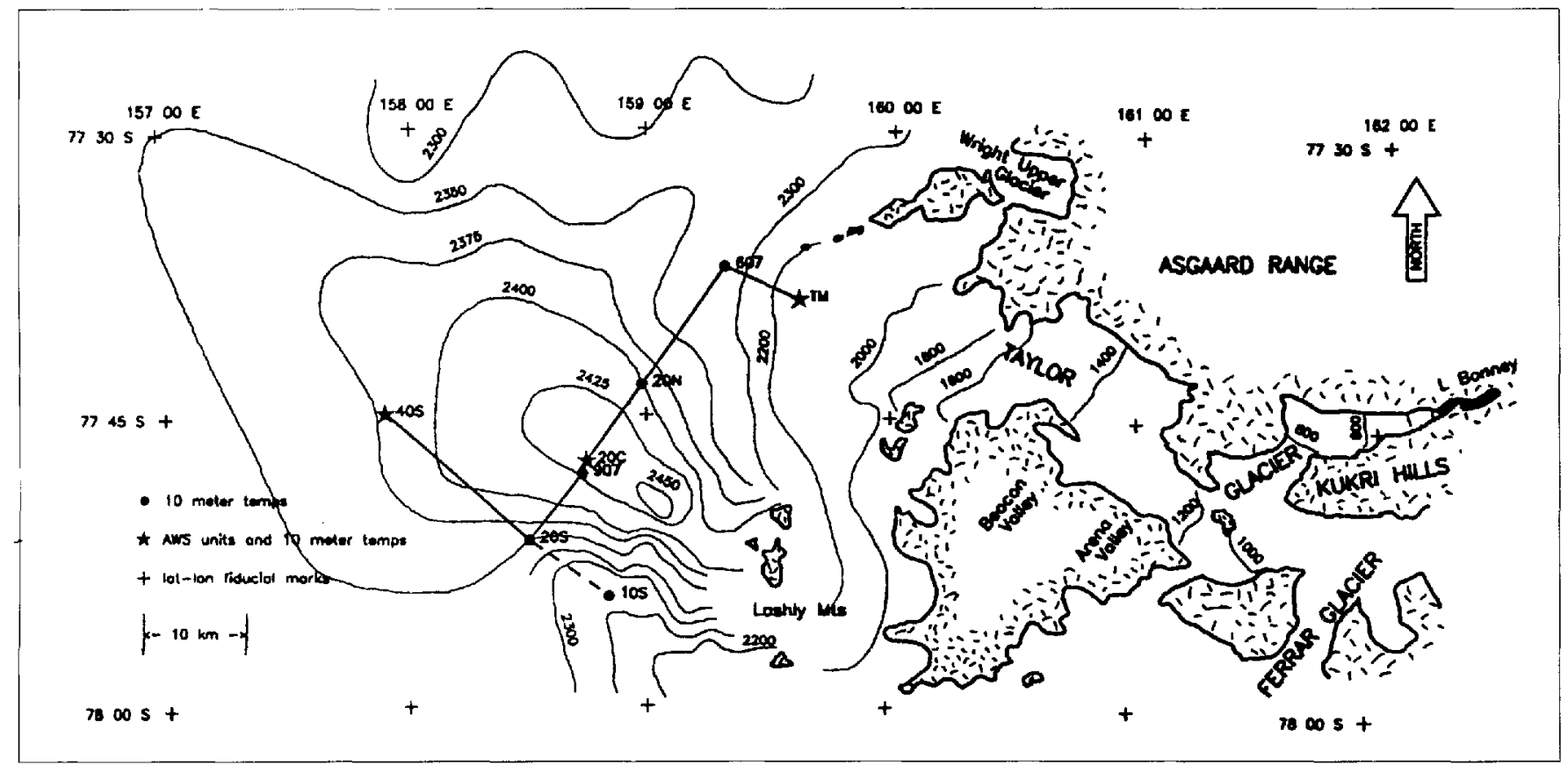

Fig. 1. Taylor Dome, Antartica, showing sites of $10 \mathrm{~m}$ firn-temperature measurements and Automatic Weather Stations (AWS). Note that the contour interval varies from 25 to $200 \mathrm{~m}$.

throughout most of the East Antarctic plateau, temperature measured at $10 \mathrm{~m}$ depth in the firn is generally taken to be equal to the mean annual surface-air temperature (e.g. Paterson, 1981, p. 188; Hooke and others, 1983 . Fortuin and Oerlemans (1990) used a data set of several hundred $10 \mathrm{~m}$ firn temperatures to show that mean annual surface temperatures at elevations above $1500 \mathrm{~m}$ on the East Antarctic plateau were controlled largely by altitude and latitude. We have measured $10 \mathrm{~m}$ firn temperatures at several locations on Taylor Dome. Our temperature data show significant spatial variability in local climate unrelated to altitude. This is a concern because of the potential impact on the interpretation of the ice-core record.

The stable-isotope method (Dansgaard and others, 1973; Paterson and Hammer, 1987) is a primary tool for paleoclimate ice-core analyses. Under certain conditions which are often met in polar precipitation, variations in the stable-isotope ratios $\delta^{18} \mathrm{O}$ and $\delta \mathrm{D}$ in snow can be related to temperature variations at the place where the ice crystals formed from the vapor phase. We need to calibrate this isotope thermometer to derive the paleotemperature signal from an ice core. A linear relation of the form

$$
T=a \delta+b
$$

has becn reported between isotopic values $\delta$ and temperature $T$ (Dansgaard and others, 1973; Robin, 1983). The constants $a$ and $b$ are determined from the isotope and tempcrature values in the area under study. Climate processes at all spatial scales can influence this calib-ration. Both $T$ and $\delta$ must be measured and all physical processes influencing their values must be understood. Possible nontemperature-related influences on the isotopic signal $\delta$ have been described elsewhere (Kato, 1978; Jouzel and others, 1982; Jouzel and Merlivat, 1984; Paterson and Hammer, 1987; Grootes and Stcig, 1992b); we address here the problem of determining representative temperatures $T$, and understanding how they are influenced by other local climate factors that may vary in both time and space.

\section{OBSERVATIONS OF $10 \mathrm{~m}$ FIRN TEMPERATURE}

We measured temperatures at $10 \mathrm{~m}$ depth in the firn at the eight locations indicated in Figure 1. Thermistors were left in hand-augered air-filled holes for several hours to equilibrate. The same thermistor string, calibrated to $0.1^{\circ} \mathrm{C}$, was used for all measurements. All obscrvations were made during late December and early January of three successive field scasons. Figure 2 shows the temperatures along the two profiles $40 \mathrm{~S} 10 \mathrm{~S}$ and $40 \mathrm{~S}-\mathrm{TM}$

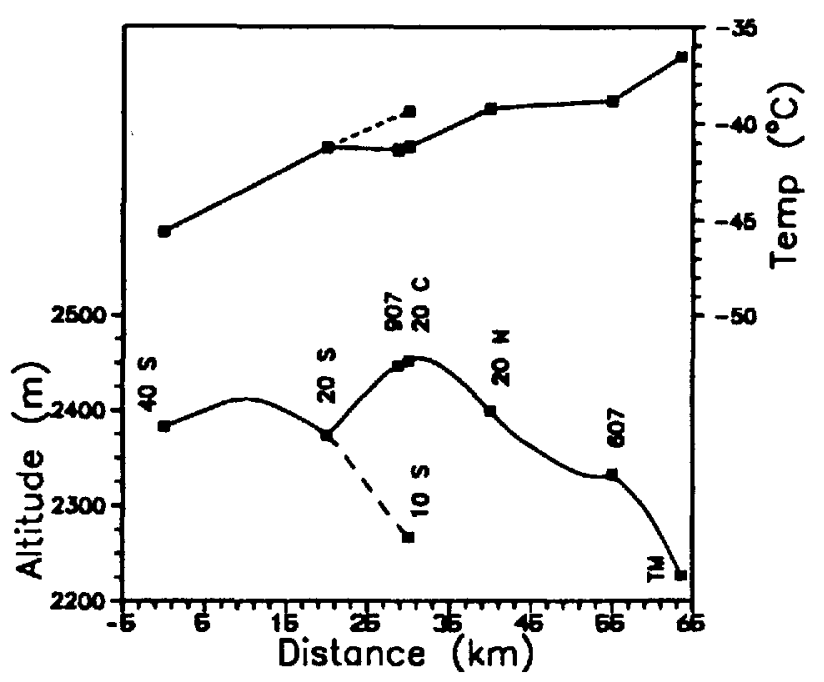

Fig. 2. Temperatures measured at $10 \mathrm{~m}$ depth in the firn. Distance and surface topography are measured along the profiles shown in Figure 1. 


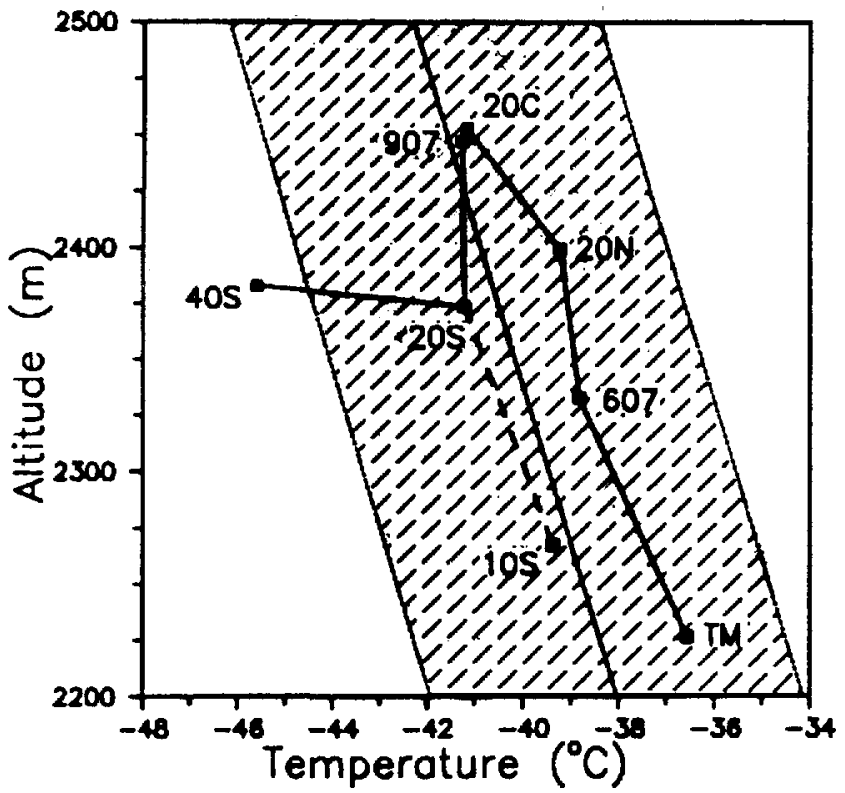

Fig. 3. Temperatures at $10 \mathrm{~m}$ depth in firn as a function of ice-sheet surface altitude. The shaded band shows the regression fit by Forluin and Oerlemans (1990) of surface temperature to altitude at $77^{\circ} 45^{\prime} \mathrm{S}$.

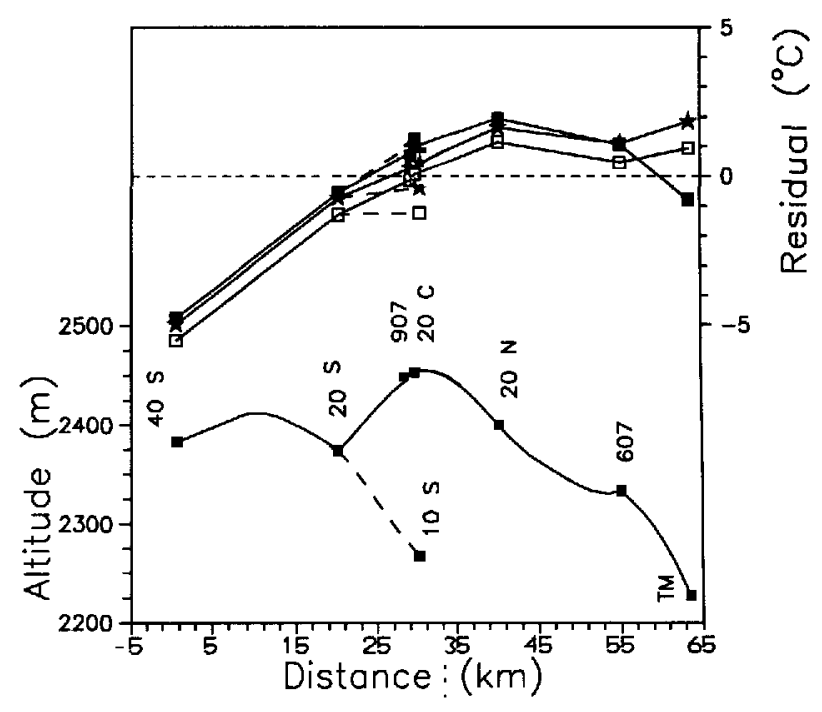

Fig. 4. Deviations of Taylor Dome fim temperalures from the best-filting altitude-temperature line for all eight Taylor Dome data points (solid squares) and from the best-filling line to seven Taylor Dome data points, excluding point $40 \mathrm{~S}$ (open squares) and from the Fortuin and Oerlemans (1990) regression line (asterisks). indicated by broken and solid lines, respectively, in Figure 1. We plot the firn temperatures against surface altitude in Figure 3.

Figure 2 shows a westward cooling trend away from the Transantarctic Mountains. The temperature data do not closely mirror ice-surface altitude. The Fortuin and Oerlemans (1990) multiple-regression analysis attributed $85 \%$ of the variance of their $10 \mathrm{~m}$ temperature data to altitude and latitude. Since their model attributed only a 0.05 deg temperature change to the $15 \mathrm{~min}$ of latitude spanned by our sites, we will not concern ourselves further with the latitude dependence. In Figure 3 we show their altitude-temperature regression line at $77^{\circ} 45^{\prime} \mathrm{S}$. Some local climate processes can be parameterized by altitude; the super-adiabatic lapse rate on the polar plateau, as found by Fortuin and Oerlemans, has been attributed to widespread adiabatic hcating of katabatic winds by Wendler and Kodama (1985). However, the large standard deviation of the Fortuin and Oerlemans study shown by the shaded band in Figure 3 reflects the inclusion of data from widely spaced parts of the continent with inherently different synoptic influences and with locally variable microclimates that influence temperature in ways not easily quantifiable in their regression model.

In Figure 3, the two profiles descending from the summit (20C-TM and 20C-10S) fall within the Fortuin and Oerlemans band, suggesting that they are subject to local climate processes similar to those at most other plateau sites. However, the slopes on these two profiles differ noticeably. The line $40 \mathrm{~S}-20 \mathrm{~S}$, to the west, has a third distinctively smaller slope. This suggests that physical processes that cannot be parameterized entirely by altitude and latitude are at work. These processes differ on the north and south flanks of Taylor Dome and cause strong relative surface cooling to the west.

We wish to separate the signal due to these unidentified factors from the signal due to altitude. 'The solid squares in the upper panel of Figure 4 show the deviations of observed firn temperatures from the best altitude-temperature line fit to our cight data points. Because the westernmost data point $40 \mathrm{~S}$ skews the bestfitting line (see Fig. 3), we plot (open squares) the deviations of all eight data points from the best-fitting altitude-temperature line for the seven other points only. Finally, the solid astcrisks show the deviations of our $10 \mathrm{~m}$ firn temperatures from the Fortuin and Oerlemans line for the interior plateau. The residuals calculated by all three methods consistently show that the temperatures get colder westward from $20 \mathrm{~N}$, in a way that cannot be accounted for by altitude alone.

\section{WEATHER-STATION DATA}

Annually averaged air temperatures (as estimated from the firn tempcratures) have inadequate temporal resolution to reveal unambiguously the physical processes acting at Taylor Dome. Figure 5 shows the difference between the average daily air temperatures from two Automatic Weather Stations (AWS) that recorded. simultaneously throughout 1992 at sites $40 \mathrm{~S}$ and $20 \mathrm{C}$ (Fig. 1). There are three features to note in Figure 5. First, there appears to be an annual cycle in the temperature difference. During the austral summer, the air temperatures are very similar at the two sites but, during the winter, $20 \mathrm{C}$ near the centre of Taylor Dome tends to be $5 \mathrm{deg}$ or more warmer than $40 \mathrm{~S}$ on the western flank. Secondly, superimposed on the annual cycle, we see cpisodes lasting $1-2 \mathrm{~d}$ during the winter when it can be as much as $20 \mathrm{deg}$ warmer at $20 \mathrm{C}$. Thirdly, we see winter periods of several days when the temperatures at the two sites are nearly equal.

Fxamination of the individual air-temperature records (not shown) from the two sites $40 \mathrm{~S}$ and $20 \mathrm{C}$ showed that 


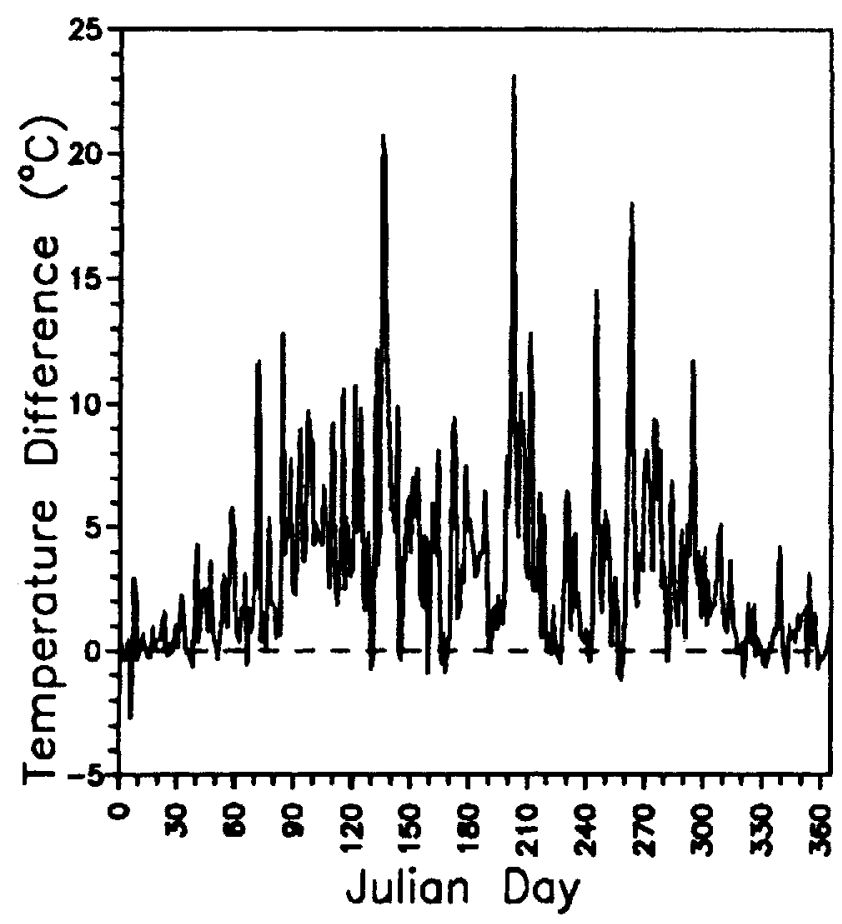

Fig. 5. Difference in mean daily air temperature between siles $20 \mathrm{C}$ and $40 S$ (temperature at $20 \mathrm{C}$ minus that at $40 \mathrm{~S}$ ) at $3 \mathrm{~m}$ above the snowe throughout 1992 . Firn temperature at site $40 S$ is colder by 4.4 deg. The two sites have similar summer temperatures but winter temperatures can be warmer by up to 20 deg at $20 \mathrm{C}$ for short time periods.

the largest wintcr-tempcrature differences coincided with cold temperatures at $40 \mathrm{~S}$. During the winter periods, when the temperature difference was very small, the temperature tended to be relatively warm at both sites or rising rapidly at both sites. The rclative warming and cooling trends at the two AWS sites during the rest of the winter do not show a simple pattern.

We find that the difference in air tempcrature in Figure 5 , when averaged over the full year 1992, accounts for $75 \%$ of the observed difference of $4.4 \mathrm{deg}$ in the firn temperatures at the two sites. The times of extreme temperature difference account for only a small fraction of the annual average temperature difference because of their short duration. The 1992 annual average air temperatures from each of the two sites were several degrees warmer than the corresponding firn temper-atures. This difference is probably due to: (a) the inversion-layer temperature gradient between the snow surface and the sensors located $3 \mathrm{~m}$ above it, and (b) sensor shields that imperfectly prevented radiative heating. Further analysis of AWS data should clarify this.

\section{PHYSICAL PROCESSES}

The trend seen in the residual temperatures in Figure 4 must result from spatial differences in the surface-cnergy balance (radiation or latent- and sensible-heat fluxes) or in the sub-surface energy fluxes or sources. We have insufficient data yet to evaluate these terms across Taylor Dome. Spatial differences or temporal changes in local energy balance result from differences or changes in meteorological processes affecting the regional or local arca. These processes, which are complex and interrelated Schwerdtfeger, 1970, 1984; Allison and others, 1993), arc the link between climate and ice cores. We now outline physical processes that could contribute to the temperature patterns that we observe.

\section{(1) Cloud-cover differences}

Snow radiates as a black body in the infrared and radiative cooling is a major control on ice-sheet surface temperatures (Crutcher, 1969; Schwerdtfeger, 1970, 1984). Snow-surface temperature tends to equilibrate with the temperature of the nearest black-body radiator above. This black body can be a cloud, which is relatively warm, or the clear sky which is relatively cold. If clouds associated with storm systems moving into the Ross Sea sometimes penetrate the Transantarctic Mountains barrier, the frequency of cloud cover could diminish with distance from the Transantarctic Mountains, causing enhanced radiative cooling of the snow surface to westward.

\section{(2) Inversion-layer strength}

Under a clear sky, strong radiative cooling leads to the persistent and strong temperature-inversion layer widely scen over icc caps. However, windier areas are known to have less-stable inversions; turbulence mixes warmer air from aloft down into the inversion layer and may totally disrupt it. Diffcrences in wind and turbulent mixing across Taylor Dome could result in a spatial gradient in the strength of the surface-inversion layer.

\section{(3) Warm-air intrusion}

Storm systems could bring warmer air up through the Transantarctic Mountains, transferring a diminishing amount of sensible heat to the surface with distance on to the polar plateau.

\section{(4) Cold-air intrusion}

Wind from the inland plateau may have a complicated flow pattern that preferentially brings colder air to the west and south of Taylor Dome.

\section{(5) Firn thermodyamics}

As yet unidentified physical processes in the near-surface firn might heat or cool the firn without altering the temperature of the snow surfacc or the air above. Latent heat of refreezing meltwater (Paterson and Clarke, 1978, internal heating of the firn by viscous wind dissipation or transfer of sensible heat deep into the firn (Clarke and others, 1987; Clarke and Waddington, 1991) would be examples. Spatial variations of such processes could account for the observed firn temperatures.

\section{DISCUSSION}

We now assess the importance of these various processes.

In summer, heavy cloud cover was often observed near the mountains to the east, while the sky remained clear to the west. However, Figure 5 shows that the firntemperature pattern results mainly from processes active in winter. In winter, the very cold temperatures at $40 \mathrm{~S}$ during periods of extreme temperature differcnce in 
Figure 5 could result when skics clcar at $40 \mathrm{~S}$ while cloud cover persists to the east.

Differences in inversion-layer strength appear to account for strong spatial gradients in $10 \mathrm{~m}$ firn temperature at Agassiz Ice Cap on Ellesmere Island in Arctic Canada (Waddington and others, 1988, 1989; umpublished data of E. D. Waddington and D.A. Fisher). The inter-dependence of katabatic winds and surface temperatures in Antarctica has bcen studied previously Schwerdtfeger, 1970, 1984; Wendler and Kodama, 1985; Bromwich, 1989; Allison and others, 1993). The case for Taylor Dome is also compelling but as yet poorly documented. The cold temperatures at $40 \mathrm{~S}$ during times of large temperature differences in Figure 5 could be cxplained by calm conditions with a strong inversion at $40 \mathrm{~S}$, while wind turbulence mixes the inversion layer at 20C. We do not yet have adcquate wind data to test this. We observe more sastrugi and scouring, features related to strong wind, on the north flank of 'laylor Dome in the vicinity of $20 \mathrm{~N}$ than elscwhere.

Hogan and others (1982) reported large changes in temperature at South Polc Station associated with incursions of different air masses on to the plateau. At Taylor Dome, during summer we have observed rising tempcrature and changes in wind direction coincident with the arrival of marine air from the Ross Sea. Similar patterns can be seen in other seasons in the weatherstation data. The relatively warm winter temperatures or warming trends associated with times of little or no temperature difference in Figure 5 are compatible with penetration of warm air masses far into the interior; however, those data are also compatible with the absence of an inversion layer due either to the formation of heavy and uniform cloud cover or to windy conditions throughout the area.

We have inadequate data on wind patterns or source areas to assess the importance of cold-air intrusions from the interior. The cold temperatures scen at $40 \mathrm{~S}$ during times of extreme temperature differences in Figure 5 are compatible with a flow of cold air around the southwest flank of Taylor Dome. However, katabatic flows tend to warm as they descend; it is unclear what temperature would be associated with such winds at 40 S. Future AWS data should resolve this.

Processes (1)-(4) all attribute the $10 \mathrm{~m}$ firn-temperature differences to differences in the mean air temperature at the snow surface. Firn thermodynamic processes (5) would attribute the temperature difference to differences in heat sources within the upper $10 \mathrm{~m}$ of firn, without a corresponding difference in air temperatures. Since Figure 5 shows that the air-temperature difference accounts for most of the firn-temperature difference, we conclude that firn processes are not a major contributing factor. In addition, there is no evidence of surface melting at Taylor Dome and a study of tirn temperatures and wind specd (personal communication from $P$. Trowbridge) indicated that the thermal effect of wind was small during experiments at site $20 \mathrm{C}$ during the summer.

Further data are needed to determine the relative impacts of these processes. Probably, no single process accounts entirely for the firn-tempcraturc pattern; however, we expect that the interplay of katabatic wind and the winter temperature inversions is very important. Cloud cover may be obtainable from satellite images. However, clouds are often difficult to distinguish from cloud-free ice surfaces. Advanced Very High Resolution Radiometer (AVHRR) images can be processed to yield the surface temperature of cloud-free areas. These images can reveal temperature patterns associated with compressional heating of katabatic winds (Bromwich, 1989) in spatial detail unattainable by an AWS network. Longer AWS records and better AWS spatial coverage would complement AVHRR data by calibrating AVHRRderived temperatures and measuring associated winds and pressures. Three automatic weather stations at Taylor Dome (Fig. 1) now measure air and snow temperatures, wind, visible insolation and air pressure. We plan to examine these data, when retrieved, for evidence of differences in air tempcrature, in vertical temperature gradient and in wind speed among the three sites throughout the year.

When we understand the modern local climate, wo will be able 10 address the impact of past local climate changes on the ice-core-derived climate record. Local climate processes can (1) alter the geochemical record in the ice, or (2) affect the ice temperatures and the calibration of the isotope thermometer, or both.

\section{Impact on the geochemical ice-core record}

Some aspects of the geochemical climate signal in the ice may be affected by changes of the local surfacetemperature regime. We must understand the processes causing these changes, so that the local geochemical signal is not mistaken for a regional or global signal.

Gas and chemistry measurements in the ice-core should be largely unaffected by microclimate-related changes in near-surface air temperature, as long as the temperature has stayed below $-15^{\circ} \mathrm{C}$. Dust and aerosol measurements should also be largely unaffected by temperature; however, they could show indirect correl-ation with temperature if differences in windiness, which may also affect dust and aerosol deposition (Cunningham and Waddington, 1993), cause the temperature differences.

Precipitation on polar ice shects tends to come from air masses that move continuously from a warmer to a colder environment such that vapor saturation is maintaincd, and precipitation and water removal are controlled by the rate of cooling. If the vapor source and atmospheric circulation do not vary with time, and if precipitation always occurs under Rayleigh conditions. (Dansgaard and others, 1973) without vapor exchanges along the path, then the stable-isotope ratios $\delta^{18} \mathrm{O}$ and $\delta \mathrm{D}$ in an ice core can reveal the difference in temperature between past and modern times at the place where the ice crystals formed from the vapor phase (e.g. Paterson and Hammer, 1987). If all precipitation originates as snow falling from above the inversion layer, the stable-isotope record should be unaffected by microclimate-related temporal changes in the surface temperature. Ice crystals known as diamond dust can form from vapor cooling within the inversion layer. The relative importance of this source of accumulation at Taylor Dome is unknown; however, it is significant at the South Pole (personal communication S. G. Warren, 1992). When this vapor 
has been brought into the area by global-circulation patterns satisfying all the above isotopic conditions, the stablc-isotope ratio of diamond dust will depend on the air temperature in the inversion layer.

A changing local temperature pattern could also change local sublimation and precipitation processes near the surface, thus affecting the stable isotopes in the firn. Snow-pit studies at Taylor Dome (Grootes and others, 1991; Grootes and Steig, 1992a) show that a significant fraction of the firn is metamorphosed to form depth hoar at some locations, particularly on the north flank. With a strong inversion layer, surface cooling and light winds, vapor from sublimating firn may move toward the surface, only to be partially redeposited locally as hoar. The hoar, -isotopically heavier than the vapor, could enrich the snow in heavy isotopes. In a windier regime, with a weaker inversion layer and warmer near-surface air temperatures, all the vapor would tend to escape from the local area without redeposition. Thus, changes in the local surface temperature and wind could cause a secondary change in the average isotopic composition of the snow.

Finally, if wind mixes or redistributes snow or diamond dust horizontally over distances comparable to the length scale of the local climate variations, the temperature pattern and the resulting isotope pattern may be out of phase or unrelated.

\section{Impact on isotope-thermometer calibration}

The coefficients $a$ and $b$ in Equation (1) can bc determined from at least three types of data sets. Linear relations have been reported between isotopic values $\delta$ of precipitation at a specific site and temperature $T$ of the precipitating cloud (reviewed by Robin, 1983, table 2). Cloud-temperature data are difficult to obtain and this technique is seldom used. Over areas of the Greenland and Antarctic ice sheets, a linear relation is commonly seen betwcen spatial variations of mean isotopic value $\delta$ of surface snow and corresponding variations of mean annual surface temperature $T$ (Dansgaard and others, 1973; Paterson, 1981, p. 324; Robin, 1983). At Taylor Dome, where the firn temperatures deviate up to $5 \mathrm{deg}$ from both the Fortuin and Oerlemans (1990) model and from the local altitude-temperature best-fit model (Fig. 4), it is not yet apparcnt how to choose representative values for the modern surface tempcrature $T$. Inappropriate values for $T$ will yield a poor modern spatial $\delta-T$ relationship and give the wrong absolutc palcotemperatures from $\delta^{18} \mathrm{O}$ in the ice core. $A$ linear relation may also be found by comparing the time series of the isotopic ratio $\delta$ in an ice core with the temperature history inferred from the temperature profile measured in the borehole (Cuffey and others, 1993). At Taylor Dome, we do not yet know whether the local spatial pattern of firn temperature has been stable for thousands of years. Therefore, we must be cautious about calibrating the isotope thermometer with a temperature history derived from borehole temperatures. In situations where the firn temperature and isotopes may respond independently to local climate conditions, it may prove to be more practical to use borehole temperatures and isotope ratios to assess the long-term stability of the local surfacetemperature pattern.

\section{Ice-divide migration}

Significant changes in the regional climate, such as the glacial-interglacial transition, clearly could force changes in local climate patterns. However, the ice-cap flow dynamics could also affect the local climate pattern. The interplay of katabatic wind and temperature-inversion strength probably makes a significant contribution to the firn-temperature variability. Since katabatic winds are controlled by surface topography, the topographic crest of an ice divide can have a wind and temperature microclimate associated with it. A moving icc divide could carry its associated microclimate across an ice-core site. Conversely, we might anticipate that the local climate zones may have remained stationary as long as the dome has remained stationary. Because Taylor Dome is centered on a region of high bedrock topography, there is reason to expect that the ice divide and any associated local climatc zones have not moved substantially over the time-scale significant to the ice core, i.e. 30000 years (Waddington and others, 1993). Ice-dynamical analysis utilizing ice-core data, radar internal-layer data and iceflow models is needed to verify this.

Until we fully understand the processes affecting the temperature distribution, we cannot be ccrtain how or if they impact the ice-core record. It is possible that similar local tempcrature patterns have introduced undetected biases into isotope calibrations or ice-core paleoclimate interpretations at other sites where the firn temperatures have been less thoroughly sampled. Our findings indicate the importance of measuring the local climate variables and carefully checking assumptions about their spatial uniformity.

\section{ACKNOWLEDGEMENTS}

We thank D.H. Bromwich, D. A. Fisher, P.M. Grootes, E.J. Steig, V. Walden, S.J. Warren and two anonymous reviewers for helpful comments. We are grateful to all those who assisted with field preparations, field measurements and logistical support in Antarctica. This research was supported by L.S. National Science Foundation grant NSF DPP-8915924.

\section{REFERENCES}

Allison, I., G. Wendler and L. Radok. 1993. Climatology of the Fast Antarctic ice sheet $\left(100^{\circ} \mathbf{E}\right.$ to $\left.140^{\circ} \mathrm{E}\right)$ derived from automatic weather stations. f. Geophys. Res., 98(D5), 8815-8823.

Bromwich, D. H. 1989. Satellite analyses of Antarctic katabatic wind behavior. Bull. Am. Meteorol. Soc., 70(7), 738-749.

Clarke, G.K.C. and E. D. Waddington. 1991. A three-dimensional theory of wind pumping. 7. Glaciol, 37 125), 89-96.

Clarke, G. K. C., D. A. Fisher and E. D. Waddington. 1987. Wind pumping: a potentially significant heat source in ice sheets. International Association of Hydrological Sciences Publication 170 (Symposium at Vancouver 1987 - The Physical Basis of Ice Sheet Modelling;, $169-180$.

Crutcher, H. L. 1969. Temperature and humidity in the troposphere. In Rex, D. F., ed. Climate of the free atmosphere. Amsterdam, ctc., Elscricr, 45-83. (World Survey of Climatology, 4.)

Cuffey, K. M., R. B. Alley, P. M. Grootes and S. Anandakrishnan. 1993. Toward using borehole temperatures to calibrate an isotopic paleothermometer in contral Grecnland. Palengeogr., Paleolimatol., Paleoecol, 98, 265-268. 
Cunningham. J. and E. D. Waddington. 1993. Air llow and dry deposition of non-scasalt sulfate to polar firn: paleoclimate implications. Atmos. Eniron, 27A n17/18), 2943-2956.

Dansgaard. W., S.J, Johnsen, H. B. Clausen and N. Gundestrup. 1973. Stable isotope glaciology. Medd. Cronl., 1972), 1-53.

Drewry. D.J. 1980. Pleistocene bimodal response of Antarctic icc Vatwe, 287 5779$), 214216$.

Drewry, D.J. 1982. Ice flow: bedrock and geothermal studies from radio-echo sounding inland of McMurdo Sound, Antarctica. In Craddork, C., ed. Antartic geoscience. Madison, University of Wisconsin Press, 977-983.

Drenry, D. J. 1983. Antartica: glaciological and geophysical folio. Cambridge, University of Cambridge, Scott Polar Research Institute.

Fortuin, J. P. F., and J. Oerlemans. 1990. The parameterization of the annual surface temperature and mass balance of Antarctica. $4 \mathrm{~m}$. Gluciol, 14, 78-84.

Grootes. P. M, and E.J. Steig. 1992a. "Tavlor Dome" ice core study, Intart. 7. U.S., $27(5), 5758$.

Grootes, P. M. and E.J. Stcig. 1992b. Uncertainties in the isotopetemperature relationship in ice cores. EOS, 73 14$), 107$.

Grontes, P. M., E.J. Steig and C. Massey. 1991. "Taylor Ice-Dome" study: reconnaissance 1990-91. Antart. 7. U.S, 26 5), 69-71.

Hogan, A., S. Barnard, J. Samson and W. Winters. 1982. The transport of heat, water rapor and particulate material to the South Polar Plateau. 7. Geophy. Res., 87(C6), 4287-4292.

Hooke, R. LeB., J.E. Gould and J. Brzozowski. 1983. Near-surface temperatures near and below the equilibrium line on polar and subpolar glaciers. Z. Gletscherkd. Glazialgeol, 19, 1-25.

Jouzel, J. and I.. Merlivat. 1984. Deuterium and oxygen $18 \mathrm{in}$ precipitation: modeling of the isotopic effects during snow formation. 7. Geoph s. Res., 89 D7). 1749-1757.

Jouzcl, J.. L. Merlivat and C. Lorius. 1982. Deuterium cxress in an Last Antarctic ice-core suggests higher relative humidity at the oceanic surface during the last glacial maximum. Nature, 299(5885), 688691

Kato, K. 1978. Factors controlling oxygen isotope composition of fallen snuw in Antarctica. Nature, 272 5648), 46-48.

Morse, D. L. and E. D. Waddington. 1992. Glacier geophysical studies for an ice-core site at Taylor Dome: year two. Antart. J. U.S., 27(5), $39-61$.
Morse, D. L. and E. D. Waddington. In press. Glacier geophysical studies at Taylor Dome: year three. Antart. 7. U.S.

Paterson, W.S. B. 1981. The physics of glaciers. Second edition. Oxford, etc. Pergamon Press.

Paterson, W.S. B. and G. K. C. Clarke. 1978. Comparison of theoretical and observed temperature profiles in Devon Island ice cap, Canada Geophy. 7. Roy. Astron. Soc., 55(3), 615-632.

Paterson, W.S.B. and C. U. Hammer. 1987. Ice core and other glaciological data. In Ruddiman, W. F. and H. E. Wright, Jr., eds. North America and adjacent oceans during the last deglaciation. Boulder, $\mathrm{CO}$, Geological Society of America, 91-109.

Robin, G. de Q. 1983. The climatic record from ice cores. In Robin G. de Q., ed. The climatic record in polar ice sheets. Cambridge, Cambridge University Press, 180195

Schwerdtfeger, W. 1970. The climate of the Antaretic. In Orvig, S., ed. Climates of the polar regions. Amsterdam, etc., Elsevier, 253355. World Survey of Climatology, 14 .

Schwerdtfeger, W. 1984. Weather and slimate of the Aniartic. Amsterdam, Elsevier.

Waddington, E. D., M. M. Magnusson, D. A. Fisher and R. M. Kocrner, 1988. Microclimate at Agassiz Ice Cap, Ellesmere Island, and implications for ice core studies. EOS., 69(44), 1211.

Waddington, E. D., J. Cunningham, D. A. Fisher and R. M. Kocrner. 1989. Microclimate and ice-corc interpretation: new results from Agassiz Ice Cap, Ellesmere Island. EOS, 70(43), 1084.

Waddington, E. D., D. L. Morse, M.J. Balise and J. Firestonc. 1991. Glacier geophysical studies for an ice core site at "l'aylor Dome". Antart. F. U.S., 26 5 ), 71-73.

Waddington E. D., D. L. Morse, P. M. Grootes and E. J. Steig. 1993. The connection between ice dynamics and paleoclimate from ice cores: a study of Taylor Dome, Antarctica. In Priticr. W. R., ed. Ice in the climate system. NATO ASI Series I, 12, 499-516.

Wendler, G. and Y. Kodama. 1985. Some results of climatic investigations of Adélie Land, Eastern Antarctica. Z. Gletscherd. Glazialgeal., 21, 319-327.

The accuracy of references in the text and in this list is the responsibility of the authors, to whom queries should be addressed. 